\title{
POLA ASUH DAN PENDAPATAN KELUARGA DENGAN KEJADIAN STUNTING PADA ANAK USIA 2-5 TAHUN DI WILAYAH KERJA PUSKESMAS BOHABAK
}

\author{
${ }^{1}$ Mirna Kawulusan, Rivolta G. M Walalangi ${ }^{1}$ Jufri Sineke ${ }^{1}$,Regita C. \\ Mokodompit ${ }^{1}$ \\ Jurusan Gizi Poltekkes Kemenkes Manado \\ Email korespondensi : acha308@gmail.com
}

\begin{abstract}
Stunting is defined as height according to age -2 standard median child growth curve. One of the causes of stunting is poor parenting practices. Family income influences a person's ability to access certain foods which affect the nutritional status of children. The purpose of this study was to determine the pattern of fostering and family income with stunting in the work area of the Bohabak Health Center, North Bolaang Mongondow Regency. his type of research is analytic observational using cross sectional design. The number of samples determined by Purposive Sampling as many as 41 people aged 2-5 years. Bivariate data analysis used Chi square test with Fisher's Exact value. The results showed the sample in the short category is $68.3 \%$ and in the very short category $31.7 \%$, the sample gets good parenting ie $63.4 \%$ and parenting less $36.6 \%$, the sample that has high family income is $22 \%$ and low family income $78 \%$. It is known that there is no significant relationship between Parenting and Stunting in children aged 2-5 years in the work area of the Bohabak Health Center. There is a significant relationship between family income with the incidence of stunting in children aged 2-5 years in the work area of the Bohabak Community Health Center. It is recommended for puskesmas especially nutrition programs to provide counseling to adolescents, women of childbearing age and pregnant women about the causes of stunting and the importance of handling the First 1000 Days of Life.
\end{abstract}

\section{Keywords: Parenting, Family Income, Stunting}

Stunting didefinisikan sebagai tinggi badan menurut usia di bawah -2 standar median kurva pertumbuhan anak (Fikawati dkk, 2017). Seorang anak dikatakan pendek apabila berdasarkan perhitungan indeks TB/U dia berada rentang -2 SD sampai -3-SD, sedangkan dikatakan sangat pendek apabila perhitungan indeks TB/U nilainya < - 3 SD (Purnamasari, 2018).

Pola asuh yang baik sangat mendukung tercapainya status gizi yang optimal, melalui perawatan yang menyeluruh dari orang tua terhadap tumbuh kembangnya. Pendidikan dan pengetahuan keluarga merupakan faktor penting dalam tumbuh kembang anak. Dengan pendidikan dan pengetahuan orang tua yang baik maka orang tua dapat menerima segala informasi tentang pengasuhan anak yang baik, termasuk memberikan makanan bergizi untuk anaknya. 
Pendapatan keluarga juga berpengaruh terhadap tumbuh kembang anak. Pada suatu keluarga dengan pendapatan rendah, ditambah jumlah anggota keluarga yang besar, akan kesulitan untuk mencukupi pangan berkualitas bagi keluarganya (Purnamasari, 2018).

Diperkirakan terdapat 162 juta balita pendek tahun 2012, jika tren berlanjut tanpa upaya penurunan, diproyeksikan akan menjadi 127 juta pada tahun 2025. Sebanyak 56\% anak pendek hidup di Asia dan 36\% di Afrika (Kemenkes, 2016).

Berdasarkan hasil Riset Kesehatan Dasar Prevalensi anak stunting di Indonesia tahun 2013 adalah (37,2\%). tahun 2013 untuk prevalensi stunting Nasional sebanyak $37,2 \%$, yang terdiri dari $18,0 \%$ kategori sangat pendek dan 19,2\% kategori pendek (Balitbangkes, 2013). Berdasarkan hasil Riset Kesehatan Dasar tahun 2013 untuk prevalensi stunting di Provinsi Sulawesi Utara sebanyak 31,4\% (Balitbangkes, 2013). Berdasarkan hasil Pemantauan Status Gizi tahun 2017 untuk Kabupaten Bolaang Mongondow Utara sebanyak 36,8\% anak yang mengalami stunting.

Berdasarkan latar belakang tersebut, mendorong peneliti untuk melakukan penelitian mengenai pola asuh dan pendapatan keluarga dengan kejadian stunting di Kabupaten Bolaang Mongondow Utara.

\section{METODE}

Penelitian ini merupakan penelitian observational dengan rancangan Cross Sectional. Penelitian ini dilaksanakan pada tanggal 22 Januari - 8 Februari 2019, tempat penelitian di Wilayah Kerja Puskesmas Bohabak Kabupaten Bolaang Mongondow Utara.

Populasi dalam penelitian ini adalah anak usia 2-5 tahun. Sampel dalam penelitian ini menggunakan rumus Lemeshow (1997) dan diperoleh jumlah sampel sebanyak 41 responden. Data yang dikumpulkan dalam penelitian ini adalah data identitas diri, data derajat stunting yang diukur melalui pengukuran tinggi badan, dan data pola asuh anak dengan menggunakan kuesioner dikatakan baik bila nilai $\geq 80 \%$ dan kurang baik bila nilai $<80 \%$, serta tingkat pendapatan keluarga yang pengambilannya melalui wawancara menggunakan kuesioner dibandingkan dengan UMP Provinsi Sulawesi Utara yaitu Rp. 2.824.286, dimana pendapatan tinggi bila $\geq$ UMP dan rendah < UMP. Analisis data secara univariat dengan tabel frekuensi dan narasi sedangkan analisis bivariat dengan menggunakan uji Chi-kuadrat pada tingkat signifikan $p<0,05$.

\section{HASIL}

Umur ibu terbanyak $19-28$ tahun $(61,0 \%)$, pendidikan terakhir ibu yang terbanyak adalah SMP berjumlah 16 orang (39,0\%), pekerjaan ibu yang terbanyak adalah IRT berjumlah 35 orang $(85,4 \%)$, pendidikan terakhir ayah yang terbanyak adalah SD berjumlah 17 orang (41,5\%), pekerjaan ayah yang terbanyak adalah Petani 27 orang $(65,9 \%)$. Responden memiliki anak terbanyak adalah keluarga yang memiliki 1-2 anak berjumlah $28(68,3 \%)$ dan responden yang memiliki jumlah anggota keluarga terbanyak adalah yang memiliki anggota keluarga 3-4 orang berjumlah $28(68,3 \%)$.

Tabel 1. Distribusi Umur, Jenis Kelamin dan Derajat Stunting Anak

\begin{tabular}{lcc}
\hline Kelompok Umur & $\mathrm{n}$ & $\%$ \\
2-3 Tahun & 25 & 61,0 \\
4-5 Tahun & 16 & 39,0 \\
\hline
\end{tabular}




\begin{tabular}{lcc}
\hline Jenis Kelamin & & \\
Laki-Laki & 27 & 65,9 \\
Perempuan & 14 & 34,1 \\
Status Gizi (TB/U) & & \\
Pendek & 28 & 68,3 \\
Sangat Pendek & 13 & 31,7 \\
\hline
\end{tabular}

Kelompok umur terbanyak berada pada umur 2-3 tahun $61,0 \%$, dengan jenis kelamin anak untuk laki-laki sebesar $65,9 \%$. Derajat stunting anak tertinggi dengan kategori pendek sebesar 68,3\%). Anak menyusui berjumlah 37 anak $(90,2 \%)$ dan tidak menyusui berjumlah 4 anak $(9,8 \%)$, anak diberi kolostrum berjumlah 37 anak $(90,2 \%)$ dan tidak diberi kolostrum berjumlah 4 anak $(9,8 \%)$, anak diberi ASI saja sampai 6 bulan berjumlah 22 anak $(53,7 \%)$ dan anak yang tidak hanya diberi ASI saja sampai 6 bulan berjumlah 18 anak $(46,3 \%)$, anak diberi ASI sesuai keinginan berjumlah 24 anak $(58,5 \%)$ dan anak yang tidak diberi ASI sesuai keinginan berjumlah 17 anak (41,5\%), anak yang masih diberi ASI pada usia 12-24 bulan berjumlah 16 anak $(39,0 \%)$ dan anak yang sudah tidak diberi ASI pada usia 12-24 bulan berjumlah 25 anak $(61,0 \%)$, anak yang diberi MPASI pada usia 6 bulan berjumlah 26 anak $(63,4 \%)$ dan anak yang tidak diberi MPASI pada usia 6 bulan berjumlah 15 anak (36,6\%), anak yang jadwal makannya teratur berjumlah 37 anak $(90,2 \%)$ dan anak yang jadwal makannya tidak teratur berjumlah 4 anak $(9,8 \%)$, anak yang makan makanan bervariasi berjumlah 22 anak $(53,7 \%)$ dan anak makan makanan yang tidak bervariasi berjumlah 19 anak (46,3\%), anak yang makan selalu didampingi berjumlah 29 anak $(70,7 \%)$ dan anak yang makan tidak selalu didampingi berjumlah 12 anak $(29,3 \%)$, anak yang dibujuk untuk menghabiskan makanan berjumlah 32 anak $(78,0 \%)$ dan anak yang tidak dibujuk untuk menghabiskan makanan berjumlah 9 anak $(22,0 \%)$.

Tabel 2. Distribusi Pola Asuh Riwayat Pemberian ASI dan MPASI

\begin{tabular}{|c|c|c|}
\hline $\begin{array}{l}\text { Pola Asuh } \\
\text { Menyusui }\end{array}$ & $\mathrm{n}$ & $\%$ \\
\hline Ya & 37 & 90,2 \\
\hline Tidak & 4 & 9,8 \\
\hline Kolostrum & & \\
\hline Ya & 37 & 90,2 \\
\hline $\begin{array}{l}\text { Tidak } \\
\text { ASI Saja sampai } 6 \text { bulan }\end{array}$ & 4 & 9,8 \\
\hline Ya & 22 & 53,7 \\
\hline $\begin{array}{l}\text { Tidak } \\
\text { ASI sesuai keinginan } \\
\text { bayi }\end{array}$ & 18 & 46,3 \\
\hline Ya & 24 & 58,5 \\
\hline $\begin{array}{l}\text { Tidak } \\
\text { Masih diberi ASI usia } \\
12-24 \text { bulan }\end{array}$ & 17 & 41,5 \\
\hline Ya & 16 & 39,0 \\
\hline $\begin{array}{l}\text { Tidak } \\
\text { MPASI sejak berusia } 6 \\
\text { bulan }\end{array}$ & 25 & 61,0 \\
\hline
\end{tabular}


Ya

Tidak

Jadwal

teratur

Ya

Tidak

Makanan bervariasi

Ya

Tidak

Makan selalu

didampingi

Ya

Tidak

Dibujuk untuk

mengahbiskan makanan

Ya
32

9

26

15

37

90,2

4

$\mathrm{n}$

22

19

29

12

70,7

29,3

78,0

22,0

Kategori pendapatan keluarga tinggi berjumlah 9 anak $(22,0 \%)$ dan kategori pendapatan keluarga rendah berjumlah 32 anak $(78,0 \%)$.

Tabel 3. Hubungan Antara Pola Asuh dengan Derajat Stunting

\begin{tabular}{|c|c|c|c|c|c|c|}
\hline \multirow[t]{2}{*}{ Variabel } & \multicolumn{4}{|c|}{ Status Gizi (TB/U) } & \multirow{3}{*}{$\begin{array}{c}\text { Total } \\
(\%)\end{array}$} & \multirow{3}{*}{$\begin{array}{c}P \\
\text { Value }\end{array}$} \\
\hline & \multicolumn{2}{|c|}{ Pendek } & \multicolumn{2}{|c|}{ Sangat Pendek } & & \\
\hline Pola Asuh & $\mathrm{n}$ & $\%$ & $\mathrm{n}$ & $\%$ & & \\
\hline Kurang & 9 & & 6 & & 15 & \\
\hline Baik & 19 & & 7 & & 26 & 0,492 \\
\hline Total & 28 & & 13 & & 41 & \\
\hline
\end{tabular}

Hasil penelitian menunjukkan bahwa anak dalam kategori pendek yang pola asuh baik yaitu 19 orang $(17,8 \%)$ dan pola asuh kurang 9 orang $(10,2 \%)$. Dalam kategori sangat pendek yang pola asuh baik yaitu 7 orang $(8,2 \%)$ dan pola asuh kurang yaitu 6 orang $(4,8 \%)$. Berdasarkan hasil analisis statistik Chi Square dengan nilai Fisher's Exact dimana $p$-value $\alpha(0,492)>0,05)$ yang berarti secara statistik tidak terdapat hubungan yang signifikan antara Pola Asuh dengan derajat stunting pada anak usia 2-5 tahun di wilayah kerja Puskesmas Bohabak.

Tabel 4. Hubungan Antara Pendapatan Keluarga dengan Derajat Stunting

\begin{tabular}{cccccc}
\hline Variabel & \multicolumn{2}{c}{ Status Gizi (TB/U) } & & \\
\cline { 2 - 3 } & Pendek & $\begin{array}{c}\text { Sangat } \\
\text { Pendek }\end{array}$ & & $\begin{array}{c}\text { Total } \\
(\%)\end{array}$ & $\begin{array}{c}\mathrm{P} \\
\text { Value }\end{array}$ \\
\cline { 1 - 3 } $\begin{array}{c}\text { Pendapatan } \\
\text { Keluarga }\end{array}$ & $\mathrm{n}$ & $\mathrm{n}$ & & \\
\hline $\begin{array}{c}\text { Rendah } \\
\text { Tinggi }\end{array}$ & 25 & 7 & & 32 & 0,018 \\
\hline Total & 3 & 6 & 9 & 41 & \\
\hline
\end{tabular}


Hasil penelitian menunjukkan bahwa anak yang dalam kategori pendek yang golongan pendapatan keluarga tinggi berjumlah 3 orang $(6,1 \%)$, golongan pendapatan keluarga kurang berjumlah 25 orang $(21,9 \%)$ dan dalam kategori sangat pendek golongan pendapatan keluarga tinggi 6 orang $(2,9 \%)$, golongan pendapatan keluarga rendah 7 orang $(10,1 \%)$. Berdasarkan hasil analisis statistik Chi Square dengan nilai Fisher's Exact dimana $p$-value $\alpha=0,018(<0,05)$ yang berarti secara statistik terdapat hubungan yang signifikan antara Pendapatan Keluarga dengan tingkat stunting pada anak usia 2-5 tahun di wilayah kerja Puskesmas Bohabak.

\section{PEMBAHASAN}

Berdasarkan pola asuh, terdapat 4 anak tidak diberi ASI dan Kolostrum dengan alasan bahwa ASI tidak keluar. Untuk anak yang mendapat ASI terdapat 18 anak yang tidak hanya mendapat ASI saja sampai 6 bulan dan tidak diberi ASI sesuai keinginan melainkan diberikan tambahan susu formula dengan alasan ibu bahwa frekuensi ASI sedikit dan anak selalu menangis ketika disusui, ibu bekerja, puting luka. Untuk anak yang sudah tidak diberi ASI pada usia 12-24 bulan yaitu 25 anak dengan alasan ibu bahwa anak sudah tidak suka ASI, sudah dibiasakan minum susu formula atau teh. Untuk anak yang tidak diberi MPASI sejak usia 6 bulan berjumlah 15 anak dengan alasan anak belum suka makan, ibu takut memberikan makan, anak sudah suka makan. Untuk anak yang jadwal makan tidak teratur berjumlah 4 anak dengan alasan ibu anak malas makan, anak hanya banyak minum susu. Untuk anak yang tidak mendapat makanan bervariasi berjumlah 19 anak dengan alasan ibu hanya menyediakan makanan yang ada saja, anak tidak suka sayur. Untuk anak yang tidak selalu didampingi ketika makan berjumlah 12 anak dengan alasan ibu bahwa anak sudah tau makan sendiri, ibu sibuk. Untuk anak tidak dibujuk untuk menghabiskan makanan berjumlah 9 anak dengan alasan ibu bahwa nafsu makan menurun, anak sudah kenyang.

Pada penelitian ini menunjukkan derajat stunting pada anak usia 2-5 tahun lebih banyak pada anak dengan kategori pendapatan keluarga rendah 32 orang $(78,0 \%)$ dibandingkan dengan pendapatan keluarga tinggi berjumlah 9 orang $(22,0 \%)$. Dengan pendapatan yang rendah biasanya mengonsumsi makanan yang lebih murah dan menu yang kurang bervariasi, sebaliknya pendapatan yang tinggi umumnya mengonsumsi makanan lebih tinggi harganya, tetapi penghasilan yang tinggi tidak selamanya meningkatkan konsumsi zat gizi yang dibutuhkan oleh tubuh, tetapi kenaikan pendapatan akan menambah kesempatan untuk memilih bahan makanan dan meningkatkan konsumsi makanan yang disukai meskipun makanan tersebut tidak bergizi (Irviani A. I \& Faramita R). Anak pada pendapatan keluarga yang rendah memiliki risiko menjadi stunting sebesar 8,5 kali dibandingkan pada anak dengan pendapatan keluarga tinggi (Lestari dkk, 2014).

\section{Hubungan Pola Asuh dengan Derajat Stunting}

Hasil analisis statistik Chi Square dengan nilai Fisher's Exact dimana $p$-value $\alpha(0,492)>0,05)$ yang berarti secara statistik tidak terdapat hubungan yang signifikan antara Pola Asuh dengan kejadian Sunting pada anak usia 2-5 tahun di wilayah kerja Puskesmas Bohabak. Pola asuh dalam pemberian makan memiliki peran dalam derajat stunting karena asupan makan sepenuhnya diatur oleh ibunya namun dalam hasil penelitian ini tidak berhubungan karena sampel yang 
diteliti kebanyakan memiliki pola asuh yang baik. Walaupun pola asuh ibu baik, pada keluarga miskin terdapat keterbatasan dalam memenuhi kebutuhan seharihari sehingga pola asuh tidak mempengaruhi masalah stunting.

Hasil penelitian ini sejalan dengan penelitian yang dilakukan oleh Kainde, dkk (2014) menunjukkan bahwa tidak terdapat hubungan yang signifikan antara pola asuh dengan derajat stunting terdapat nilai p-value 0,464 $(<0,05)$. Hasil penelitian yang dilakukan oleh Ni'mah dan Muniroh (2015) juga menunjukkan tidak ada hubungan antara pola asuh ibu dengan stunting terdapat nilai $p$-value 0,928 $(>0,05)$.

Hasil penelitian yang dilakukan Syabandini, dkk (2018) juga menunjukkan hasil uji chi-square didapatkan $p$-value $=0,198$ yang dapat disimpulkan bahwa pola asuh ibu tidak memiliki hubungan dengan derajat stunting.

\section{Hubungan Pendapatan Keluarga dengan Derajat Stunting}

Berdasarkan tabel 24 diatas hasil analisis statistik Chi Square dengan nilai Fisher's Exact dimana p-value a $(0,018)<0,05)$ yang berarti secara statistik terdapat hubungan yang signifikan antara pendapatan keluarga dengan kejadian Sunting pada anak usia 2-5 tahun di wilayah kerja puskesmas Bohabak. Sebagian besar $(78,0 \%)$ pendapatan keluarga balita berada dibawah upah minimum provinsi Sulut yaitu kurang dari 2.824.286. Pendapatan keluarga yang kurang dapat mempengaruhi status gizi anak karena sebagian besar pendapatannya untuk konsumsi belum tentu mencerminkan bahwa apa yang dimakan tersebut sudah baik dalam mutu gizinya. Keluarga yang memiliki pendapatan kurang akan membeli kebutuhan pangan yang harganya terjangkau dan beberapa harga bahan makanan yang mahal cenderung tidak dipilih atau dibeli sehingga makanan yang disajikan tidak memenuhi kebutuhan gizi yang diperlukan.

Hasil penelitian dari Rahmad dan Miko (2016) menunjukkan hasil uji statistick diperoleh nilai $p$-value $0,026(p<0,05)$. Anak balita yang mengalami stunting resikonya 3 kali lebih besar disebabkan oleh pendapatan keluarga yang rendah dibandingkan dengan keluarga yang berpendapatan tinggi di Kota Banda Aceh.

Hasil penelitian Hapsari (2018) juga menunjukkan bahwa ada hubungan yang bermakna antara pendapatan keluarga dengan stunting terdapat nilai $p$-value $0,004(<0,05)$. Pendapatan rendah akan mempengaruhi kualitas dan kuantitatas bahan makanan yang dikonsumsi oleh keluarga. Makanan yang didapat biasanya akan kurang bevariasi dan sedikit jumlahnya terutama pada bahan sumber protein, vitamin, dan mineral.

Hasil penelitian ini sejalan dengan penelitian yang dilakukan oleh Ngaisyah (2015) bahwa ada hubungan antara pendapatan keluarga dengan stunting terdapat nilai $p$-value $0,036 \quad(<0,05)$. Meningkatnya pendapatan akan meningkatkan peluang untuk membeli pangan dengan kualitas yang lebih baik, sebaliknya penurunan pendapatan akan menyebabkan menurunnya daya beli pangan yang baik secara kualitas maupun kuantitas.

Setiawan, dkk (2018) juga menunjukkan ada hubungan yang bermakna antara tingkat pendapatan keluarga dengan stunting terdapat nilai $p$-value 0,018 $(<0,05)$. Orang tua dengan pendapatan keluarga yang memadai akan memiliki kemampuan untuk menyediakan semua kebutuhan baik primer maupun sekunder anak. Keluarga dengan status ekonomi yang baik juga memiliki akses pelayanan kesehatan yang lebih baik. Anak pada keluarga status ekonomi rendah cenderung mengkonsumsi makanan dalam segi kuantitas, kualitas, serta 
variasi yang kurang. Status ekonomi yang tinggi membuat seseorang memilih dan membeli makanan yang bergizi dan bervariasi.

\section{KESIMPULAN}

Persentase derajat stunting pada anak usia 2-5 tahun dalam kategori pendek berjumlah 28 anak $(68,3 \%)$ dan untuk kategori sangat pendek berjumlah 13 anak (31,7\%). Anak yang dalam pola asuh baik berjumlah 29 orang (70,7\%) dan pola asuh kurang berjumlah 12 orang (29,3\%). Anak yang dalam golongan pendapatan keluarga tinggi berjumlah 9 orang $(22,0 \%)$, golongan pendapatan keluarga kurang 32 orang $(78,0 \%)$. Tidak ada hubungan yang signifikan antara pola asuh dengan derajat stunting. Ada hubungan yang signifikan antara Pendapatan Keluarga dengan derajat stunting pada anak usia 2-5 tahun di wilayah kerja Puskesmas Bohabak. Bagi puskesmas khususnya program gizi dapat memberikan penyuluhan kepada remaja, wanita usia subur dan ibu hamil tentang penyebab stunting dan pentingnya penanganan 1000 Hari Pertama Kehidupan.

\section{DAFTAR PUSTAKA}

Badan Penelitian dan Pengembangan Kesehatan RI. (2013). Riset Kesehatan Dasar Indonesia Tahun 2013. Jakarta: Depertemen Kesehatan RI.

Fikawati, S, Syafiq. A. \& Veratamala. A. (2017). Gizi Anak dan Remaja. PT Raja Grafindo Persada, Depok.

Hapsari, W. (2018). Hubungan Pendapatan Keluarga, Pengetahuan Ibu tentang Gizi. Tinggi Badan Orang Tua, dan Tingkat Pendidikan Ayah dengan Kejadian Stunting Pada Anak Umur 12-59 Bulan. Fakultas Kedokteran Universitas Muhammadiyah Surakarta. 1(1:7).

Ibrahim A. I \& Faramita Ratih. (2015). Hubungan Faktor Sosial Ekonomi Keluarga Dengan Kejadian Stunting Pada Anak Usia 24-59 Bulan DI Wilayah Kerja Puskesmas Barombong Kota Makassar Tahun 2014. Public Health Science Journal. 6 (2:72).

Kementrian Kesehatan (2016). Pusat Data dan Informasi Situasi Balita Pendek. Jakarta Selatan: Kementrian Kesehatan Republik Indonesia. www.depkes.go.id/resources/download/pusdatin/.../situasi-balitapendek2016.pdf. Diakses pada tanggal 26 April 2018 pukul 02.14.

Kainde O. K, Malonda N. S. H, \& Kawatu P. A. T (2014). Hubungan Pola Asuh Ibu Dan Berat Badan Lahir Dengan Kejadian Stunting Pada Anak Usiia 1336 Bulan Di Wilayah Kerja Puskesmas Tuminting Kota Manado. Fakultas Kesehatan Masyarakat Universitas Sam Ratulangi. 1(1: 4).

Lemeshow S. DKK. (1997). Besar Sampel dalam Penelitian Kesehatan. Yogyakarta Gadjah Mada University Press.

Lestari W, Margawati A, \& Rahfiludin, M, Z. (2014). Faktor Risiko Stunting Pada Anak Umur 6-24 Bulan Di Kecamatan Penanggalan Kota Subulussalam Provinsi Aceh. Jurnal Gizi Indonesia. 3 (1:42). 
Masrin, Paratmanitya Y, \& Aprilia V. (2014) Ketahanan Pangan Rumah Tangga Berhubungan Dengan Stunting Pada Anak Usia 6-23 Bulan. Jurnal Gizi Dan Dietetik Indonesia. 2 (3:112).

Ni'mah, C \& Muniroh L (2015). Hubungan Tingkat Pendidikan, Tingkat Pendidikan, Tingkat Pengetahuan Dan Pola Asuh lbu dengan Wasting dan Stunting Pada Balita Keluarga Miskin.Media Gizi Indonesia. 10 (1: 86).

Ngaisyah, D. (2015). Hubungan Sosial Ekonomi dengan Kejadian Stunting Pada Balita Di Desa Kanigoro, Saptosari, Gunung Kidul. Jurnal Medika Respati. 10 $(4: 67)$.

Purnamasari, D. U. (2018). Panduan Gizi dan Kesehatan Anak Sekolah. Penerbit ANDI, Yogyakarta.

Rahmad, A. H. A, \& Miko, A. (2016). Kajian Stunting pada Anak Balita Berdasarkan Pola Asuh Dan Pendapatan Keluarga di Kota Banda Aceh. Jurnal Kesmas Indonesia. 8 (2:63-79).

Setiawan, E, Machmud R, \& Masrul (2018). Faktor-Faktor Yang Berhubungan Dengan Kejadian Stunting pada Anak Usia 24-59 Bulan di Wilayah Kerja Puskesmas Andalas Kecamatan Padang Timur Kota Padang Tahun 2018. Jurnal Kesehatan Andalas. 7 (2: 280-281).

Syabandini, I. P, Pradigdo S. F, Suyatno, \& Pangestuti D. R (2018). Faktor Risiko Kejadian Stunting Pada Anak Usia 6-24 Bulan Di Daerah Nelayan. Jurnal Kesehatan Masyarakat. 6 (1: 499). 